\title{
Significance of Female Encounters in the Paintings of F. N. Souza
}

\author{
Mandakini Sharma, Ila Gupta \& P. N. Jha \\ IIT Roorkee, India
}

\begin{abstract}
:
Women and painting are coupled with each other from the dawn of the art throughout the world. In Indian painting, women have frequently been depicted from the ancient era till today. In this context, their beauty and physical charm are more preferred than any significant values. In modern Indian painting, Amrita SherGill is probably the first Indian female artist, who contributed some significant themes in respect of womanhood during 19th century. Then, many prominent artists portrayed woman in various forms but Francis Newton Souza has represented them in a strange but powerful manner. His paintings played an indispensable role to give Indian art a new direction and to enhance its true realm in respect of 'modern'. He has done thousands of sketches and paintings on woman in naked and semi-naked condition but his approach is very singular than that of others. Beauty and noble attitude of woman are entirely avoided by him and only the vicious and distorted figures are depicted. Thus, the paper aims at discussing the symbolic significance of female figures in some of Souza's paintings. The discussion will be based on some critical approaches for seeking various dimensions regarding the nude female depictions and erotica with their strange facial composition. The female paintings of Souza are representatives of the erotic and sensual manifestation with their stark nudity. At the same time they also possess the ironical statements and satire on the society and create an apprehension in the viewers.
\end{abstract}

Keywords: Francis Newton Souza, female body, painting, Indian art, nudity.

\section{Introduction}

The enigma and charm of woman has always remained the most depicted thing in art from the very dawn of history. This phenomenon has also been considered the most contradictory aspect throughout the world. The primary evidences of art practices have been found in the cave temples of many countries including India, where prehistoric people had contributed a lot to express their thoughts on the wall of caves through painting. Those paintings are particularly related to their lifestyle and surroundings and woman has been depicted in a fewer scenes when compared to man. This bias of representation may be true or may not be true because almost all paintings have been made with geometrical or linear forms and it is very difficult to guess the gender of those figures.

After the advent of Indus valley civilization, woman's portrayal has been done frequently and it continued. In this long voyage of painting, Indian art has been influenced and patronized by various people of different countries and religions. This concept of patronization or courtship has been broken during the 19th century after the arrival of company style, when artists got various platforms to learn art practices and to expose their creativity. In this list of precursors of modern painting the most prominent are Ravi Verma, Amrita Sher-Gill, Abnindranath Tagore, Yamini Roy, who came up with some new ideas and techniques during the 19th century. 
During the 20th century, the art of representation has suddenly changed its course and meaning due to a group of artists in Bombay. They were called 'the Progressives', (Progressive Artistic Group), and Francis Newton Souza had been considered the founder of PAG. The major members of this group were, M.F. Hussain, F. N. Souza, Saiyad Haider Raja, K. H. Aara, and V. S. Gaitondey. This group has been considered the backbone of modern Indian paintings because each artist of this group has contributed a lot to give Indian art a new direction and make it more authentic. The art of Francis Newton Souza has always attracted numerous connoisseurs either for appreciation or for critical evaluation of a world of distorted figures with evil faces. This very configuration of devil-like creatures is the most prominent aspect in the paintings of Souza including woman. The portrayal of woman in his paintings has been mostly done with huge genitals and vicious smile in naked and semi-naked condition, which somehow indicates some gender politics in respect of woman. Thus, in this paper some paintings of Souza have been critically observed to frame out the symbolic significance of woman depiction in his paintings.

Francis Newton Souza (1924-2002) was born in Goa, a Portuguese state of India in a middle class family and his father died when he was very young. During his school days, he was expelled from the school for drawing some naked graffiti in the school toilet. While at Sir J. J. School of art in Bombay for his art education he was suspended in 1945 for supporting Quit India Movement. Later in 1947 he had founded Bombay Progressive Artistic Group (PAG) along with a few other artists, which gave art a new direction. The main artists of the group were M. F. Husain, Sayad Haider Raja, and K. H. Aara, F. N. Souza, S. K. Bakre.

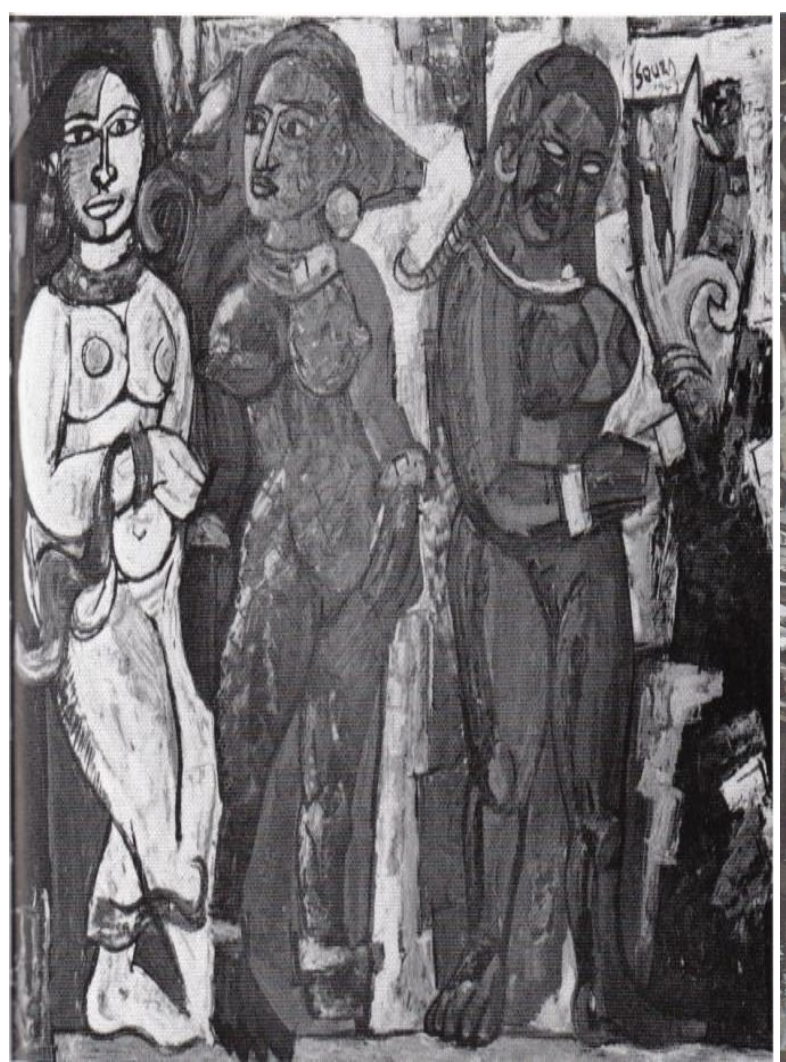

Fig.1 The Three Girls (1949)

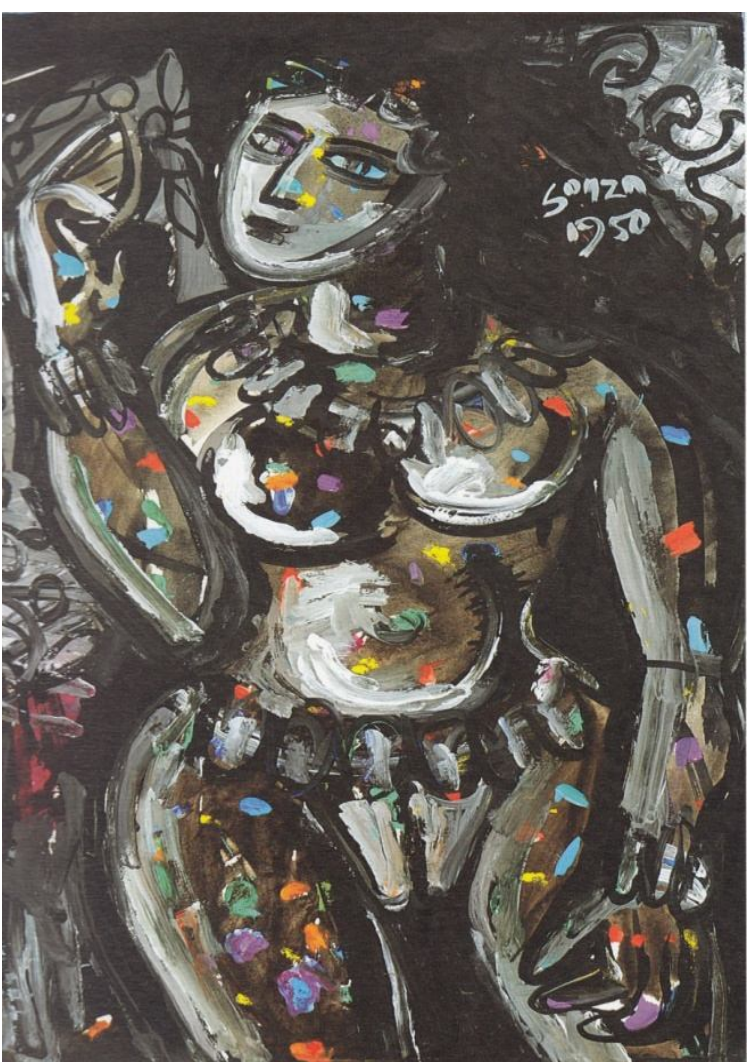

Fig.2 Untitled (1950)

Fig.1 The Three Girls, Souza, Oil on board, Size unknown, Galerie Pallette, Zurich, Source: Kurtha 2006

Fig.2 Untitled, Souza, Water \& Oil Colour on Paper, 20x12 inches, Image Curtsey, Dhoomimal Art Gallery, New Delhi 
The main objective of this group was to synthesize the Indigenous art traditions with the modern European and American art movements by drawing the basic inspiration from the ancient Indian art traditions. The main agenda of the group was to give Indian art a modernistic approach, but their basics were highly influenced by the indigenous sculpture and painting. This modernistic approach has been derived through various Western and European art styles but the spirit of this has remained entirely Indian. The first exhibition of this group was organized in 1949 in Baroda and in Bombay, where, the group gained large scale attention. Their manifesto was very fascinating and was clubbed with a number of aspects including Indian primitive and folk style, temple erotica, and western 'isms'. The 'absolute freedom for content and technique' is the only preferred aspect because they were not bound by any art movement or school but their representations were channelized through the 'laws of aesthetic order, plastic coordination and color composition' (Souza, 1994). They are considered as harbingers of truly modern and vigorous Indian art. Later, Mohan Samant, Vasudeo S. Gaitonde and Krishen Khanna joined the group in 1950s and there are numerous artists, who got inspired by the progressive module of PAG.

Therefore, the group has led its followers on the zenith of individualistic styles of representations. Souza had left India during 1949 and went to live in London. He has gained name and fame nationally and internationally through his unique style of depiction. He has done numerous nude paintings of women throughout his career and usually portrayed them in sensuousness and erotic terms. He generally gave preference to heavy body structure with huge sexual organs and strange faces. He is not only inspired by erotic temple imagery of Khajuraho but also had some influences of western modern artists including Titian and Eduart Manet, Henri Matisse, Picasso, Goya and many more. Let us consider the following paintings for analysis.

In the image (fig.1), Souza has painted the same postures, which are frequently depicted in Khajuraho; he has painted them in the same erotic style. These three standing figures are entirely looking like the yakshis of Mathura and Khajuraho. They are voluptuous and sensuous but the grace, which is a dominant feature of almost all temple erotica, is changed here into a shameless attitude. According to Kapur, the girls in the painting are looking like the whorish woman of Bombay (1978). In another image (fig. 2), Souza has again painted a voluptuous woman, similar to that temple erotica but made her genitals much bigger. The impact of the sculpture of Khajuraho and Mathura has been represented in an imaginative manner in most of his paintings. According to Bhardwaj, women have a very important place in Souza's life, in his pictorial world too they take the central stage (2009) (emphasis added).

His curiosity for the anatomical forms of human body can be guessed through his deep restlessness, and secretly watching his mother at bath from a hole. He made her nude paintings on the wall of his school, as he admitted," I used to watch her bathe herself through a hole I had bored in the door... I drew her on the walls and prudes thought I was rude. I can't see (2010)." His curious attitude and obsession for female nudes has been discussed by numerous critics and artists and it is believed by many of his collectors that he had approximately made over 12,000 sketches of nude erotic women (Raj). He also experimented with some chemical effects; those paintings are known as chemical paintings. In these chemical paintings he has used some printed images after burning or scratching some of the parts of these images which are closely related to man-woman intimacy. The paintings of Souza, which depict woman as a subject, are highly sensuous, and full of powerful appeal with their voluptuous body. In some of the paintings, he often enhanced the size of genitals with seductive appeal. In one of the images (fig.3), he has portrayed a young woman with catchy gestures with pen ink. The face of the girl is looking very small than the entire body and her breasts have been dramatically large, which is very unnatural. In most of his ink drawings on paper, he has 
portrayed woman with soft lines but in a highly sensuous manner. Their gestures are quite erotic and free from any social boundaries. In other image (fig.4), there is a standing nude with deep red shade and the woman is again portrayed to create the sense of offerings for its onlookers. Her gaze is entirely frontal and her posture appears to be very inviting. This particular style of depicting woman has been frequently followed by Souza, in which the giant size woman has been associated with the hyperbolic representation of genitals. Sometimes, he painted them with simple flat background of colour and sometimes he distorted the figures with rickety nose and devil like structure.

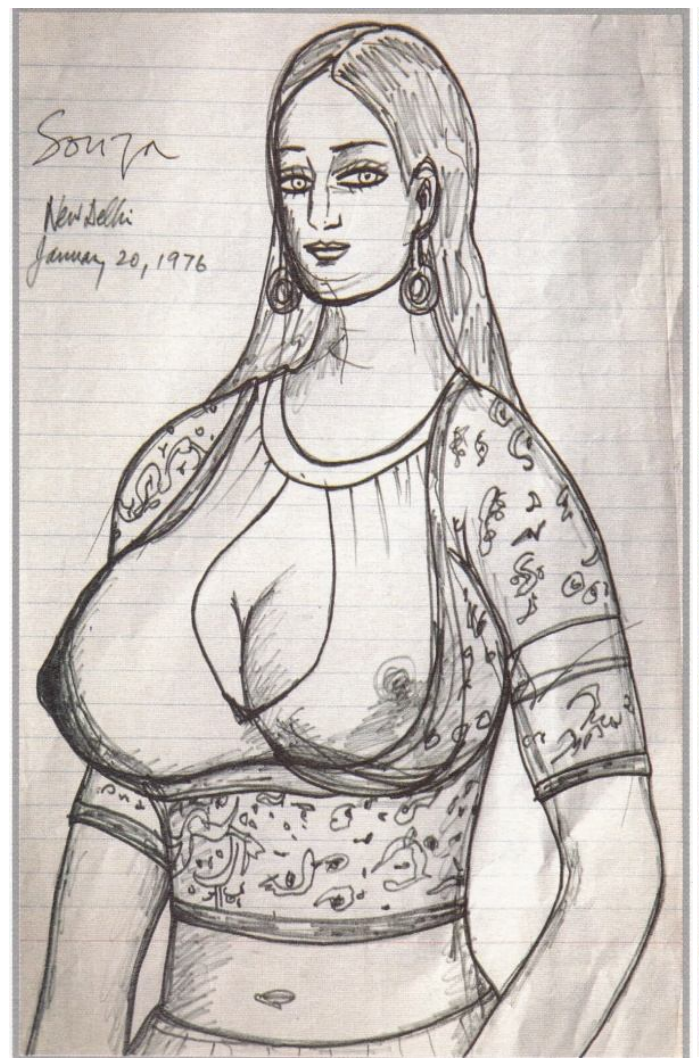

Fig. 3 Untitled (1976)

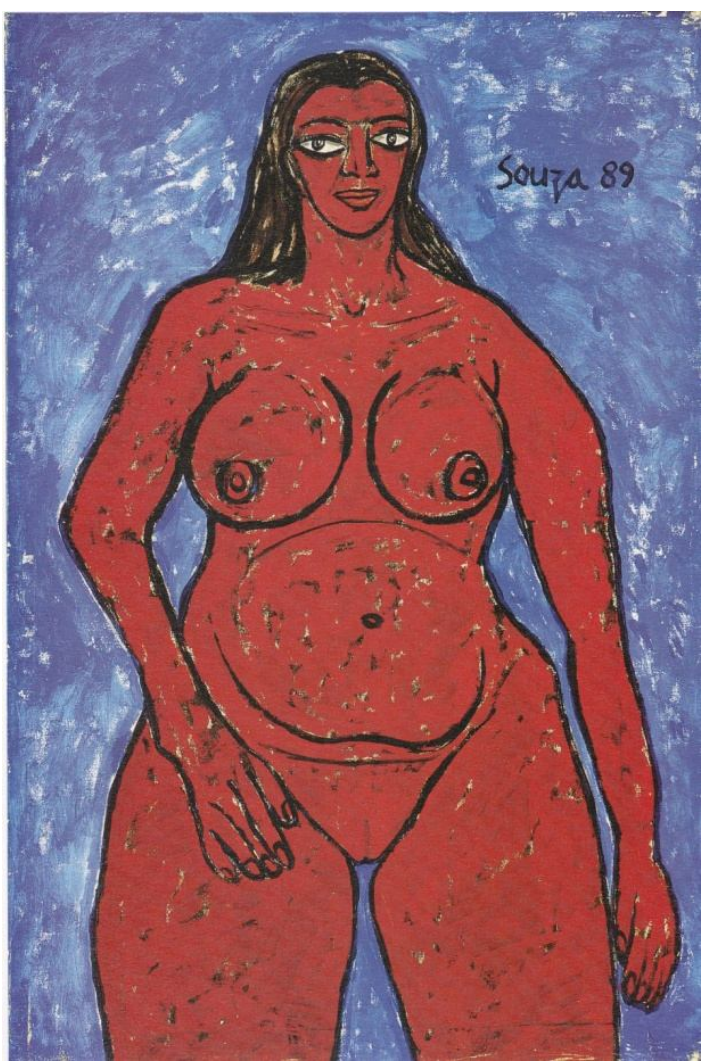

Fig.4 Untitled (1989)

Fig.3 Untitled, Pen \& Ink on Paper, 1976, 11x9 inches, image Courtesy, Dhoomimal Art Gallery New Delhi Fig.4 Untitled, Souza, Oil on canvass, size-60x 40 inches, image courtesy, Dhoomimal Art Gallery, New Delhi

The portrayal of woman in the painting of Souza has been done with strong erotic appeal and stark nudity. They seem to be quite shameless about their body display and their genitals are formed in hyperbolic manner, which create an impression of offering. They appear to rotate the gaze of the beholders through their staring attitude. So the paper will shed light on the various dimensions behind this portrayal of women on Souza's canvas.

\section{Discussion}

Souza has been blessed with a fecundity of imagination and intuition which were considered not often as a virtue but sometimes as offensive, so Souza had to face rejection in the initial stages. Such experiences were faced by Souza from the scholastic days when he was expelled from the school for doing nude graffiti on the walls. Souza's attitude was very rebellious and for his anti-British activities he was expelled from the J. J. School of Arts in 1945 (Ratnam 2005). His obsession for the female figure could be seen through such stories but his way of representing them was quite different, very new and not entirely acceptable to the Indian society at that time. In respect of the portrayal of 
woman, beauty and charm is the most depicted aspect of Indian paintings from the earliest time. Souza, on the contrary, has distorted this perception of beauty and the stereotype of shy and modest woman. He has created demonic figures, which are far from such noble virtues of shyness and modesty; they are just what they are or what the artist made them to be.

In this context, the art of representation is simply based on the perception of artist first and then the viewers. In India, from a very long time, portrayal of woman has been done on the basis of some pre-decided aspects found in books and treatises, for instance the Chitrasutra and many more. According to these sutras, woman must be beautiful, and full of delicacy, well-proportioned and fairer in complexion. These ideals of depicting woman had been followed in a large number from the ancient times to the 19th century. Then, some modern artists like Amrita Sher-Gill, Jamini Roy, Rabindranath Tagore and many more looked at this subject in a different manner. In this context, the role of Sher-gill cannot be overlooked for representing village women with their sad faces in mannerist style. She was probably the first and foremost artist who raised such serious issues about woman's life, which are not related to her physical beauty and outer appearance but those issues that led its viewers into their realistic situations. Afterwards, numerous artists have experimented with women portrayal as per their own styles and approaches. But in the case of Souza, woman depiction has been mostly done to frame out her urge for self-exposure with erotic desires. This kind of woman may not be found before in the history of Indian paintings, one who offers herself to seduce her viewers, or be engaged in an erotic act. The woman in Souza's painting is not beautiful and wellproportioned; she is highly dramatized and desperately represents her inner lure for invitation.

It is already discussed that Souza has always remained solicited by the voluptuous female body which he molded as per his imagination and evaluation after combining with the pan-Indian woman stereotype found in sculpture. This stereotype with large breasts and huge hips depicted in Indian temple erotica is followed by Souza. After some time, the genitals were turned into much bigger objects and a sense of dramatic illusion dominated his painted themes. This illusion can be differentiated by the devil-like structure of women, who are filled with the bitterness of humanity and the otherness of beauty. In this way, the beauty, which is proved to be an enchanted persona in the development of aesthetic appeal for artistic representation, has been served in the form of ugliness. These kinds of images have been preferred by Souza because the meaning of beauty is also dependent on the various analyses and sometimes on the individual's experience. The thing, which is beautiful and pleasing for one may be ugly to another..

Souza has initiated his own narration regarding the beauty of the female image and he highlighted the genital parts rather than the charm and attractiveness of the face. This may be his way of representing thing on the canvass but he depicted only what he wanted to and for this he has been criticized too. But, apart from this criticism, his paintings represent a perfect rhythm of color application and lyrical harmony with sarcastic approach. As Marwah (1976) argues the "ballooning breasts and monstrous buttocks are a feature repeated in a number of drawings in his exhibition of January 1976. This facility and loose emphasis has as much to do with arrangement as with association; it will be seen that Souza is more successful when he is direct vulgar, oblivious, and bold and always more than when he attempts to be lyrical". The artistic endeavor of Souza has started form the J. J. School of arts (in 1940) and then the voyage of experimentation has reached to its zenith internationally.

He probably was the first post Independent Indian artist, who had resided abroad and gained prosperity and fame. He is not only known for such flaming nudes but also for his remarkable sense of handling colors through structures and self-developed style of composition. In respect of woman portrayal, he has mainly made three styles of paintings, one with pen ink on 
paper, other with color and the last one with chemical alterations. In the earliest phase of his paintings, the influence of Indian erotic imagery can be seen, where some of the paintings were depicted naked and some semi-naked. Numerous paintings of his were highly influenced by the paintings of prominent western artists of Paris school and the influence of Pablo Picasso can be seen on most of his paintings, particularly on portraits. Picasso has painted many women's portraits in which the faces are strangely divided into some distorted forms. Melly also vouches for the influence of Picasso on Souza who was his contemporary (Melly 2005).

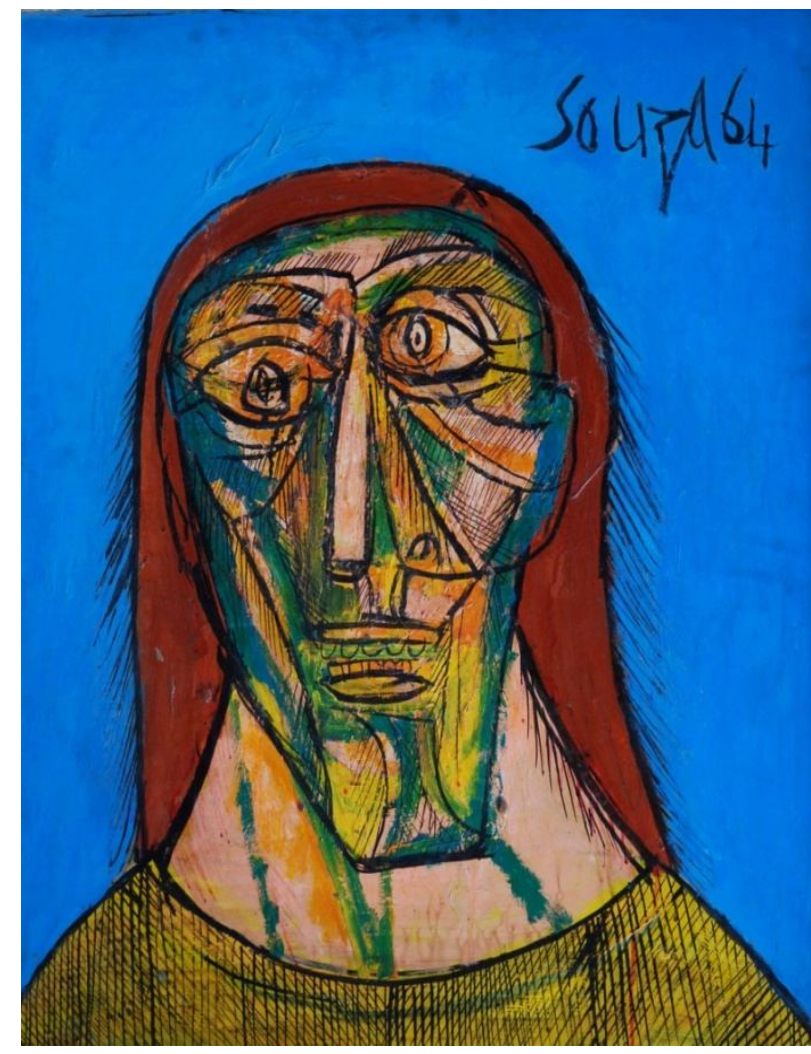

Fig. 5 "Head"(1964)

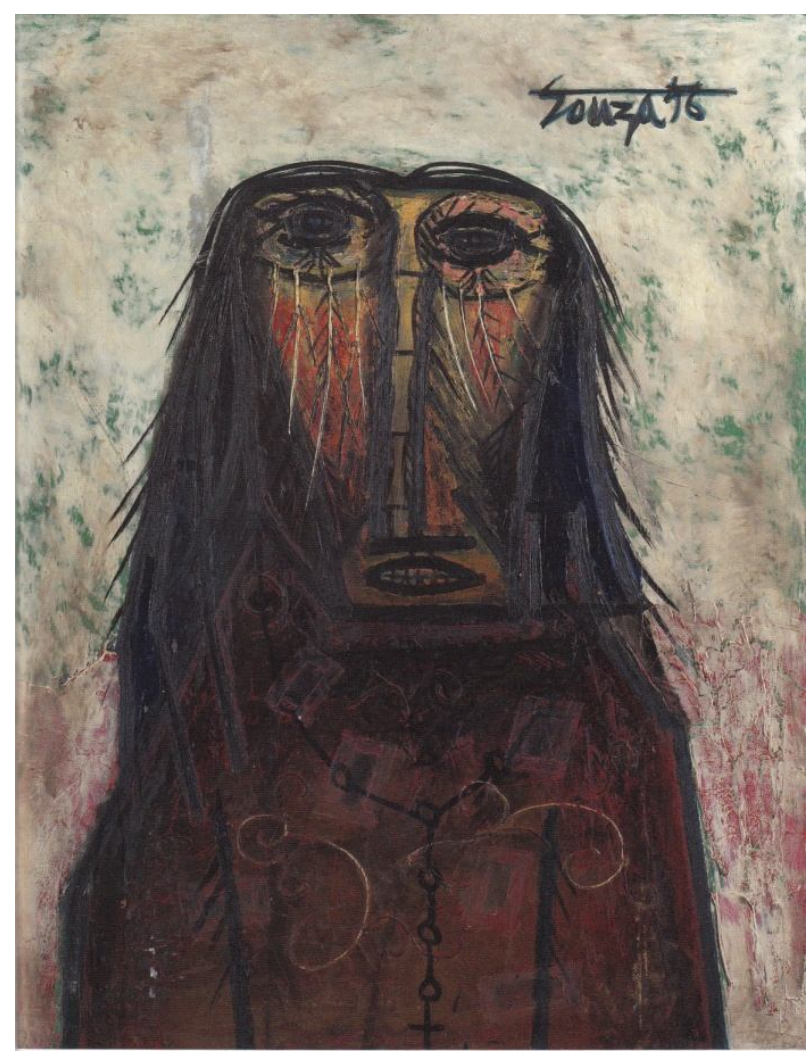

Fig. 6 Head of a Woman (1956)

Fig. 5 "Head" by Souza, 1964, Size. 30x 24 inch, Acrylic on Board

Source-https://ridingtheelephant.files.wordpress.com/2010/04/1964-head-30x24inch-acrylic-on-board.jpg Fig.6 Head of a Woman, Souza, Oil on Board, size- 95x 60 cm. (38x24"), Source: Kurtha 2006

This kind of distortion of faces can be seen in Souza's paintings (Fig-1), where faces are made as looking like some hanging objects on the surface. The actual form of natural appearance has been lost due to these tilted and moving-like shapes, which somehow attack directly or indirectly the consciousness of the viewers. In the case of woman portrayal he mostly uses vibrant colors with powerful strokes. These paintings are mostly done in acrylic and oil medium with bold color strokes and vibrant shades of orange, green against yellow background. Then the black lines are marked on the painting to give it final touches, which is particularly made in a cross-hatching technique. This technique has been used by Souza in approximately all paintings, and according to Alkazi (a Delhi based curator), this pattern is closely related to the private parts of women (Kurtha 2006). Souza also talks about this technique. This pattern has been made with two parallel lines, which are crosshatched on the other side and this can be seen in all of his work including still lifes, landscapes, portraits and compositions (Souza 1959 in Words \& Lines). The other preferred element of Souza in woman's depiction is naked woman in semi-abstract form with heavy breast and broad hips. 


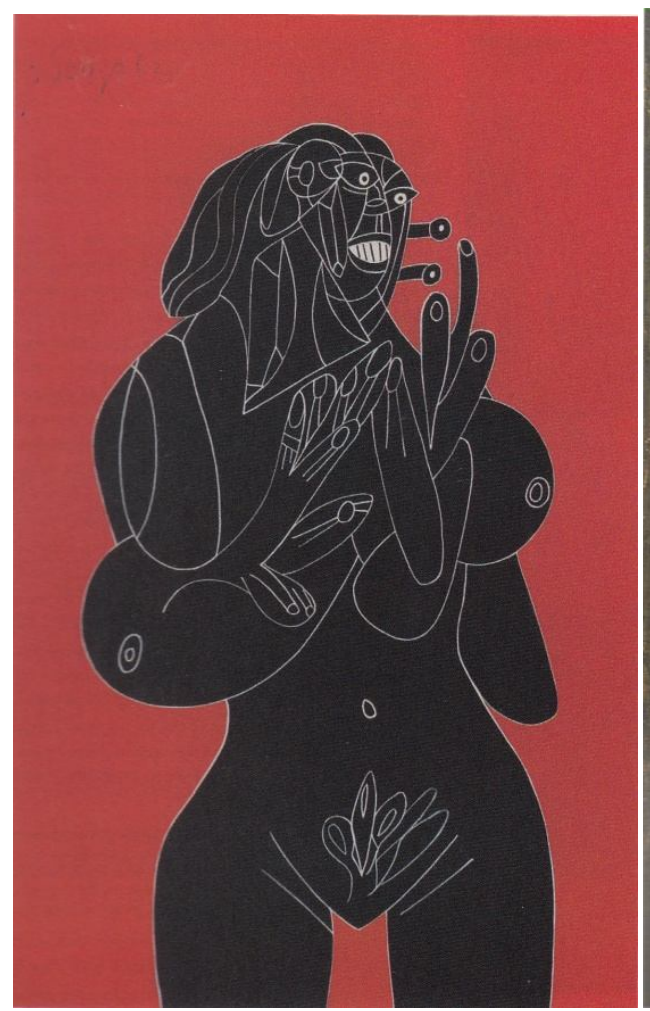

Fig.7 Lady in Black (1962)

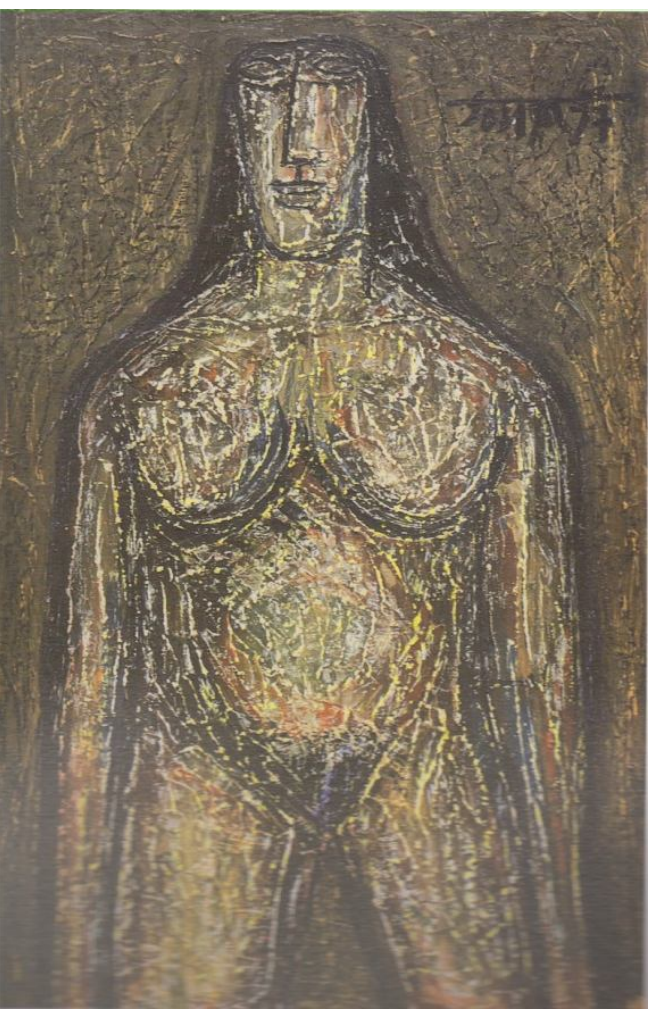

Fig. 8 Amazon (1957)

Fig.7 Lady in Black, Souza, Tempera on paper, size- 36x23, Kumar Gallery, New Delhi, Source: Kurtha 2006 Fig.8 Amazon, Souza, Oil on board, 36x24 inches, image Courtesy, Dhoomimal Art Gallery New Delhi

The sensual nude of Souza, which has been modelled on the erotic temple imagery, is now transformed in to distorted forms. For instance, in the image titled 'Lady in Black', despite the sensuous imagery the woman is turned into a horrifying figure with a distorted face and body. In another image titled, 'Amazon', Souza has painted a woman with brownish and yellowish tones and gave a rough texture through thick lines. This harshness of lines has changed the delicacy of woman's body into harshness. The face is also depicted as very long, which makes the painting destructive. The treatment of gestures and other things is also very strange and disturbing but the signature style of his paintings remains the same. The style of making big breasts and vulva is again same in this kind of painting too.

Such images have strong physical structure, which may be a result of his fascination towards voluptuous woman. As Souza was inspired by the temple erotica of Khajuraho and Mathura he turned his fascination of women's body in the exaggerated image, which became his signature style. Souza derives a sensual delight in man-woman relationship which he mentions thus: "I have no desire to redeem myself or anybody else because man by his very nature unredeemable, yet he hankers so desperately after redemption. I wanted to hang myself on the cross with my hands and feet nailed to it...to have arrows quivering in my neck like flies, while in the sweetness of lovemaking....to reposes in absolute bliss, the bliss of Ananda (1959)". The repetition of sensual nudes and erotic display in his paintings may be a result of fetishism. Sometimes the pudendum of the figure has been made extremely larger than the actual size and the black color is used to highlight it. The concept of women showing her vulva with heavy breast is much familiar with the Indian nude squatting goddess named Lajja Gauri (fig.10); only the posture has been changed in Souza's painting. The Lajja Gauri is recognized as a mother goddess of ancient India and the mother of sexual 
worship, always depicted as her legs apart and showing her vulva (Martin 2012, Tiwari 1985, Sankila1960, Kramrisch 1956). In Souza's paintings women are depicted in sitting postures showing their pudendum. In this context Kapur aptly observes, "Souza has often quoted the Indian tradition as a sanction for his own erotic imagery" (1978).

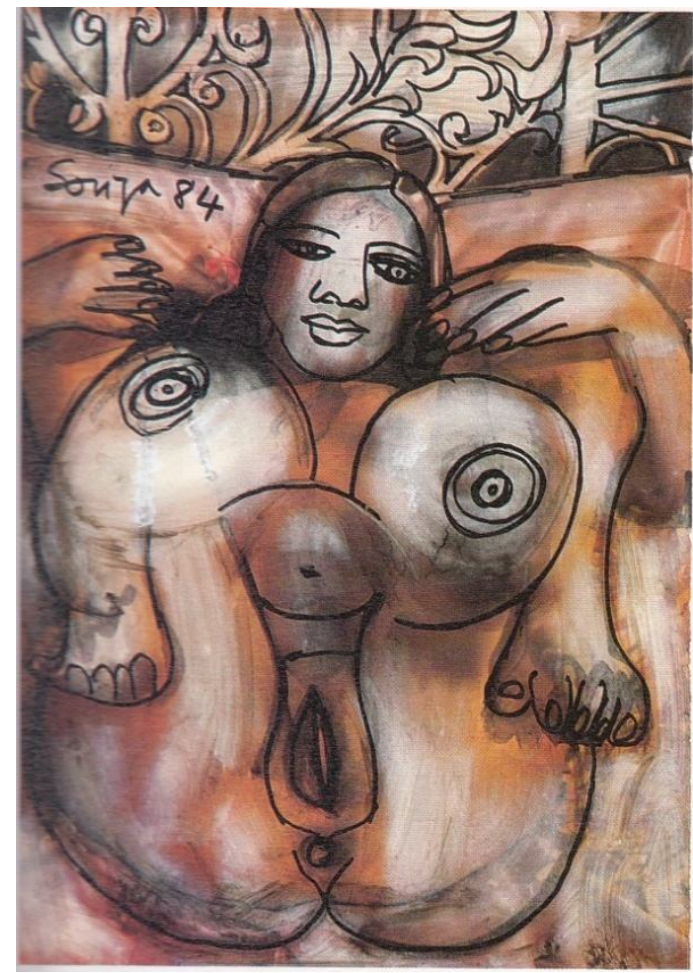

Fig. 9 Untitled (1984)

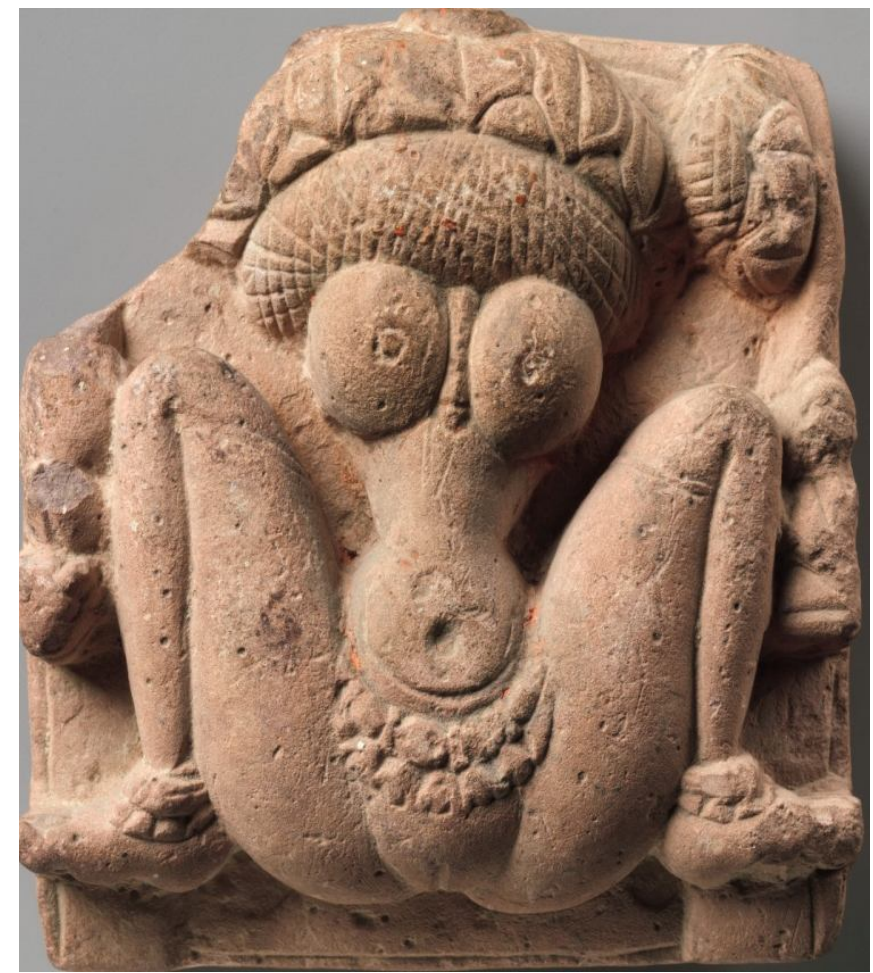

Fig.10 Lotus Headed Fertility Goddess, Lajja Gauri

Fig. 9 Untitled, Souza, chemical alterations on paper, 11x8 inches, image Courtesy, Dhoomimal Art Gallery New Delhi

Fig. 10 Lotus Headed Fertility Goddess, Lajja Gauri, ca. 6th century, India( Madhya Pradesh), sandstone sculpture, dimensions: H. 4 1/16 in. $(10.3 \mathrm{~cm})$; W. 4 1/16 in. $(10.3 \mathrm{~cm}$.$) , Samuel Eilenberg Collection, Bequest$ of Samuel Eilenberg, 1998, The Metropolitan Museum of Art Source. qhttp://images.metmuseum.org/CRDImages/as/original/DP253528.jpg

The first evidence of Lajja Gauri goddess was found on the cylinder seals of Indus valley which was later adopted frequently in so many forms without affecting the basic idea sexual worship associated with it. This worship is also practiced in contemporary times in Assam (India), where a goddess named Kamakhya has been sculpted in the same posture with her legs apart showing her vulva. Then the tenet of sexual worship and its depiction through art form has been practiced in India. In the context of Souza, as it has already been mentioned that he has been inspired by the Indian temple erotica, goddess Lajja Gauri must have drawn his attention for being powerful and a unique sculpture. It represents the sexuality and the worldwide phenomenon of sexual union in the form of goddess. Souza has also accepted that he has been much fascinated by this aspect female sexuality and the bliss of sexual union and when he saw this goddess, who invites everyone for sexual act, he just adopted this very aspect of shamefulness in most of his paintings. In his paintings, he did not directly adopt the same posture but only tried to depict the same kind of woman with inviting attitude through showing her genitals in highly emphasized manner; it somehow leads its viewers into a strange world. In this strangeness, there are a plenty of symbolic arrangements, where one can relate his or her own ideology with this stunning and shocking attitude of the female. In this 
way, this particular display of shocking the spectator with such kind of taboos is highly synchronized with Souza's own imaginative power in the depiction of woman.

Then, there are hundreds of sketches and paintings, which captured the same shocking treatment like the goddess of sexuality. The icon of sexual worship has been often subverted by Souza because the goddess entirely belonged to the realm of worship while his woman is only meant for erotic display. The goddess Lajja Gauri is particularly associated with fertility, procreation and pregnancy before its structural display but Souza's painted woman is far away from such association and represents the socio-political issues related to the objectification of woman's body. Moreover, the women depicted in his paintings are mundane and they can be anything but part of the ritualistic display.

Sometimes, Souza also portrayed the same posture of Lajja Gauri in his chemically altered paintings, in which a woman has been shown as showing her vulva (fig.9). In this image (fig.9) Souza has depicted a nude woman who displays her genitals, but unlike Lajja Gauri (fig.10) the face of the woman in this painting is fully shown with a seductive appeal. Thus, the fertility aspect of Lajja Gauri has been replaced by Souza with stark and sensual nudity.

Thus, it can be said that Souza had a deep interest in female anatomy and erotic representation in ancient Indian art but curiously he adopted this very erotic appeal in a strange manner. The gestures of women are quite enticing because they seem to encounter the spectators with a seductive glance and disturb them with their lecherous attitude. The Indian patriarchy with its discriminatory attitude does not approve of a woman who displays her desire with an inviting attitude. On the contrary it is considered offensive. The ideal woman of ancient Hindu mythology like Sita of the Ramayana is more preferred by society and the same stereotype of an ideal woman has been imposed upon Indian woman. So, the women of Souza can be considered as an irony in such society governed by phallocentric social norms. The women are depicted as per the notions of such society or the will of the artist who is male. The adolescent obsession with woman's nudity and the tempestuous life that he had had must have deeply influenced his portrayal of nudes. Souza had suffered throughout his life from the childhood till the last days of his life. In childhood he has lost his father and suffered due to chicken pox and in his studies he faced many barriers. Though he was a great artists and the founder of PAG, he had to face many hurdles at that time. "In his life, as in his work, Francis Newton Souza defied social and artistic conventions with untiring verve. This served him well for half his career as a painter. During the latter half, however, failed marriages, tempestuous love affairs, alcohol, drugs and long stretches of deprivation and solitude took their toll”( Padgaonkar 2002) .

\section{Conclusion}

It can be said in conclusion that the erotic depiction of women must have been done by the artist to quell his psychological restlessness as he was very much troubled by his fate and destiny in his personal life. The woman depiction in the paintings of Souza may be a reflection of his negative and positive attitude for woman because he was very much obsessed with woman throughout his life. At the same time, it may be also an approach to criticize the orthodox society because as an artist he had the freedom to express his views on anything of his choice. In his paintings, woman is portrayed as full of lust and ugliness, which represents on the one hand the artistic urge to paint what he wants and his defiance of the establishment on the other. Because art is not only used to represent the feelings of individuals but also used to deal with social dilemmas and unpleasant experiences. Art is also used sometimes for healing personal problems which cannot be expressed directly but can be 
ventilated through painting. Portrayal of woman has been one of the most challenging things for the artists. Souza's approach is quite sociopolitical and exclusive in itself, where woman may serve to frame the uttermost bitterness. Though, he was an admirer of erotic and novel approach of Indian and European art, he is more possessed by the voluptuous and sensuous female body of Indian temple imagery. He is also known as a passionate being and considered a lover and as well as a hater of the feminine so, it may said that this kind of projection of woman is a response to such traumatic experiences. He may figure out a way to come out from his deep love towards such sensual imagery through distorting the previously accepted icons. On the other hand, it may be a way to express his anger or may be a medium to shock people through subverting the previously depicted female icons. Therefore, his paintings have devil-like figures, in which faces are constructed with horrifying or vicious gestures and the phenomenon of the six limbs of Indian paintings has been fully distorted by Souza. The woman may somehow objectify through such representation because their sexuality and vicious attitude is preferred only in most of his paintings. The distortion of female anatomy cannot be taken entirely in a negative manner because it represents his powerful approach to take this subject into other dimensions. He is probably the first Indian modern artist, who painted this kind of woman and changed the beautiful representation into horrified one but as per the feministic perspective, it may not be accepted. His flaming nudes are very much related with the ancient Indian goddess of sexuality but she was associated with fertility first rather than sexual invitation. In Souza's paintings, the procreative or reproductive aspect of womanhood has been almost neglected and the sexuality with vicious attitude has come to dominate. The temple erotica of Khajuraho and other sculpted forms have certain limits and acceptable too on the bases of artistic dimensions but the naked woman of Souza's painting has crossed all the limits. For instance, they are not beautiful, they are not well-proportioned, their skin is very dark with scratching on it, they are shameless, and have oversized genitals, often invite its onlookers to engage in erotic act and so on and so forth. His inspiration and artistic representation are entirely derived from the ancient artistic traditions of India but his style and techniques, handling the surface, treatment of color, space management very much belong to the western artistic traditions. Thus, it can be observed that Souza has created a hell like world of his own through painting where, these greedy and lusty women celebrate their nudity with their shameless attitude.

\section{References:}

1. See- Nilima Raj in Times of India, http://articles.timesofindia.indiatimes.com/2010-0505/people/28275641_1_francis-newton-souza-world-auction-record-fn-souza

2. Walther F. I. (2002), "Masterpieces of Western Art: A History Of Art in 900 Individual Studies from the Gothic to the Present Day", Taschen Publication, pp.491

3. Webster S. (2004), "Eve's Daughter/ Modern Woman: a Mural by Mary Cassatt", University of Illinois Press,pp.22

4. See http://www.livemint.com/Leisure/NffpJ2a8pMW3WgRWUuCNHK/The-resurrection-of-FNSouza.html, for "The Resurrection of F. N. Souza” by Anindita Ghose( 2010)

5. Kurtha A. (2006), "Francis Newton Souza: Bridging Western and Indian Modern art", Mapin Publishing Pvt. Ltd. Ahmadabad, pp.41-42.

6. Geeta K. (1978), "Contemporary Indian Artists”, Vikas Publishing House, pp.20-21

7. "F. N. Souza, Words and Lines"( first published (1959) by Villiers Pub.) second edition by Nitin Bhayana Publication, New Delhi,

8. Sankalia H. D.(1960), "The Nude Goddess or "Shameless Women" in western Asia, India and SouthEastern Asia", Artibus Asia, Vol-23, No-2, pp.111-123 
74 | Significance of Female Encounters in the Paintings of F. N. Souza

9. Tiwari N. J.(1985), "Goddess Cult in Ancient India' Sundeep Prakashan

10. Martin L. M.( 2012), “The Goddess Lajja Gauri: Origins on the Footsteps of the Universal Goddess of Sexuality", Create-space Independent Publishing Platform; Lrg. edition

11. Kramrish S.(1956), "An Image of Aditi Uttanapad", Artibus Asia,pp.259-7

12. Padgaonkar D.(2002) See- http://articles.timesofindia.indiatimes.com/2002-04-21/all-thatmatters/27119768_1_francis-newton-souza-modern-indian-art-paintings

13. Melly G. (2005), "F. N. Souza- Religion and Erotica", Barklem.com Print \& Publishing London.

14. Marwah M. (1976), "Francis Newton Souza- Expression in Style”, Lalit Kala Contemporary, No-22, September.

15. Bhattacharya K. S. (1994), "Trends in Modern Indian Art", M.D. Publications Pvt. Ltd. India.

16. Bhardwaj V. (2009), "Francis Newton Souza", Dhoomimal Art Gallery, New Delhi.

Mandakini Sharma is a Research Scholar, Fine Arts, Department of Humanities and Social Sciences, IIT Roorkee.

Dr Ila Gupta is Professor \& HoD, Department of Architecture and Planning \& Joint Faculty in HSS, IIT Roorkee.

Prof. P. N. Jha is Professor, Department of Humanities and Social Sciences, IIT Roorkee. 